Comite has important powers - such as over whether unsuccessful laboratories should be closed, or new ones opened and the technicians' and administrators' union, affiliated to the communist-led CGT, has been campaigning ever since for its voice to be heard again in that forum.

Chevènement agrees, and hasty changes are being made in order to allow technicians and administrators to attend the autumn meeting of the Comité. Beyond that, there must be a reform of CNRS statutes, which will probably wait for the National Colloquium; but the reform will be thorough, and could even involve the abandonment of the present two-tier directorship of CNRS, which has a scientific president and an executive director with overlapping responsibilities.

In a further move, the Ministry of Research and Technology has begun to appoint its own staff. They will be organized in missions d'orientation, concerned with the various goals of Chevènement's policy. Directors have been named for four. "Renewable energy and conservation" will be headed by Philippe Chartier, an expert in biomass from the Institut National de la Recherche Agronomique; 'biotechnology"' by Pierre Douzou, an ex-professor at the Museum of Natural History; "electronics" by Abel Farnoux, a television-tube manufacturer; and "employment and the conditions of work" (a matter of great concern to Chevènement, and the government as a whole) by an ex-cabinet maker and present assistant lecturer on working conditions at the University of Paris IV, Albert Detraz.

Robert Walgate

\section{British universities}

\section{Job losses inevitable}

News is emerging from British universities on how they plan to contract along the lines indicated by the University Grants Committee early in August. Not surprisingly, those universities singled out for the largest cuts in their recurrent grants over the next three years are among the first to react. Some estimate that they need to lose between 50 and 150 academic posts and up to 450 non-academic posts. Although all concerned hope that posts can be lost through early retirement and voluntary redundancy, it seems that compulsory redundancies are inevitable.

The biggest problem for universities singled out for cuts in income of more than 20 per cent is that action needs to be taken quickly. The senate of Brunel University, for example, is this week considering a report from a working party which recommends losing 110 non-academic posts, preferably by the end of this year, and 50 academic posts by April 1982.

The University of Aston in Birmingham, which says that it must do away with 150 academic and 450 non-academic posts to comply with the grants committee's wishes, has a

\title{
London to respond with more committees
}

The University of London, which has been agonizing over its future organization for some time, has now set up four subject review committees to advise on the resource allocation most likely to maintain high academic standards. This move comes just a few weeks after the university court told the constituent colleges how much money they will have to spend in the current academic year and shortly before the Committee on Academic Organisation, under its chairman Sir Peter SwinnertonDyer, is due to issue its final report on how the university should be reconstructed.

The committees, which have been established too late to have much bearing on this year's allocations, have nevertheless been charged with the task of reporting quickly. The hope is that recommendations made early in 1982 can

similar problem. Its decision last week to inform the Department of Employment that 95 staff will be redundant within a month aroused strong opposition from the Association of University Teachers, the academics' trade union, which threatened to take the university to court at the first hint of compulsory redundancy. The university administration claims that these redundancies are for non-academic staff who have already opted to take early

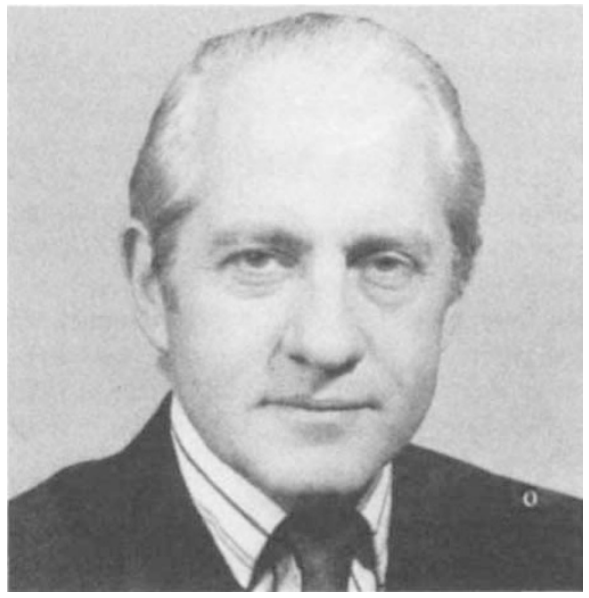

William Shelton, MP for Streatham in London, who has replaced Neil Macfarlane as Britain's UnderSecretary responsible for science in the Department of Education and Science

retirement or voluntary redundancy with compensation of up to nearly three times annual salary, but compulsory redundancies seem inevitable sooner or later.

Other universities, however, are taking it a bit more slowly. The University of Bradford plans to meet its 30 per cent drop in income by $1983-84$ by losing between 150 and 180 academic staff over three years. Consultations between the senate and heads of departments should result in a strategy by December.

Universities with more modest cuts in income are also taking more time, some of be used in shaping the university to its reduced grant in future years.

The move may also provide alternatives to the recommendations made by the Swinnerton-Dyer committee in its interim report. Those included the unpopular suggestion that Chelsea. College be closed and that some of the smaller colleges should merge.

Four independent chairmen have been appointed to the committees whose detailed membership will be announced later. The committees are on physical sciences, under the chairmanship of Sir Sam Edwards from the University of Cambridge; biological sciences, under Sir James Beament of the University of Cambridge; languages under Professor $\mathrm{J}$. Cruickshank from the University of Sussex; and social studies under Sir Alec Cairncross of the University of Oxford.

Judy Redfearn

them hoping to get by without compulsory redundancy. The University of Cambridge plans to shed 100 academic posts by lowering the compulsory retirement age from 67 to 65 years and by filling only essential posts that fall vacant. It plans to make further savings by, amongst other things, abolishing a student travel fund, curtailing sabbatical leave and abolishing examiners' fees. And at the University of Bristol, where it has been suggested that academics take a cut in salary, no decision has yet been taken. Much still needs to be resolved, however, before the future shape of the British university system becomes clear. During the next few weeks, universities will be presenting the grants committee with detailed plans, some of which will go against the committee's orginal advice. The University of Bradford, for example, would prefer to cut its physics and chemistry departments rather than biology. And the University of Leeds plans to make cuts across the board before resorting to selective cuts between departments.

Some universities are clinging to one last hope: that Sir Keith Joseph, new Secretary of State for Education and his new UnderSecretaries, William Waldegrave for higher education and William Shelton for science, can be persuaded to give the universities more time. Judy Redfearn

\section{Polish universities \\ Poised to strike}

Solidarity members at Krakow's Jagiellonian University and the nearby Mining and Metallurgical Academy (AGH) have declared a state of "strike readiness" in protest against unilateral amendments by the Ministry of Science, Higher Education and Technology to the new draft law on higher education. Many 